Proc. Indian Acad. Sci. (Chem. Sci.), Vol. 105, No. 6, December 1993, pp. 373-391.

(C) Printed in India.

\title{
Purification of drinking water by irradiation. A review
}

\author{
NIKOLA GETOFF \\ Institut für Theoretische Chemie und Strahlenchemie, der Universität Wien und Ludwig \\ Boltzmann Institut für Strahlenchemie und Strahlenbiologie, Währingerstr. 38, A-1090 Wien, \\ Austria

\begin{abstract}
The present review deals with the possibilities of water purification by UV-light, solar energy in combination with catalysts (e.g. $n$ - $\mathrm{TiO}_{2}$ ), as well as by using ionizing radiation (e.g. high energy electrons or $\gamma$-rays). The various methods are illustrated by typical examples concerning the degradation of aliphatic and aromatic halogenated pollutants in water. Some probable reaction mechanisms initiated by light or ionizing radiation are also given.
\end{abstract}

Keywords. Water purification; pollutants; degradation; photolysis; radiolysis.

\section{Introduction}

Water is the most important life factor for all living systems. As a consequence of the rapid development of various industries, the application of fertilizer, pesticides etc. in modern agriculture, the production and combustion of fossil fuels etc., there has been a strong overloading of water resources. On the other hand, the chlorination of drinking water (containing humic substances) for the purpose of disinfection leads to the formation of a number of toxic compounds (Rock 1974; Hutzinger et al 1982; Getoff 1986a). Hence, a subsequent purification of the water, e.g. by filtration through activated carbon, is necessary.

Careful investigations by various laboratories in the recent years proved that biological resistant pollutants in water can be decomposed by UV-light, solar energy in the presence of special catalysts, e.g. $n$ - $\mathrm{TiO}_{2}$, and ionizing radiation. All these three possibilities are later illustrated by examples and critically discussed. Based on the present state-of-the-art a comparison between them is made with respect to their technical application.

\section{Photoinduced degradation of water pollutants}

\subsection{Using VUV-and UV-light}

In the last decades, a number of papers have been published about the photoinduced decomposition of water pollutants. Only some of them will be briefly mentioned in the frame of this review, since further papers on nearly the same topics are also on the programme.

Naturally, a direct photochemical degradation can be achieved only when the incident light (vacuum-UV-quanta: $\lambda<200 \mathrm{~nm}$ or UV-light: $\lambda>200 \mathrm{~nm}$ ) is absorbed by the 


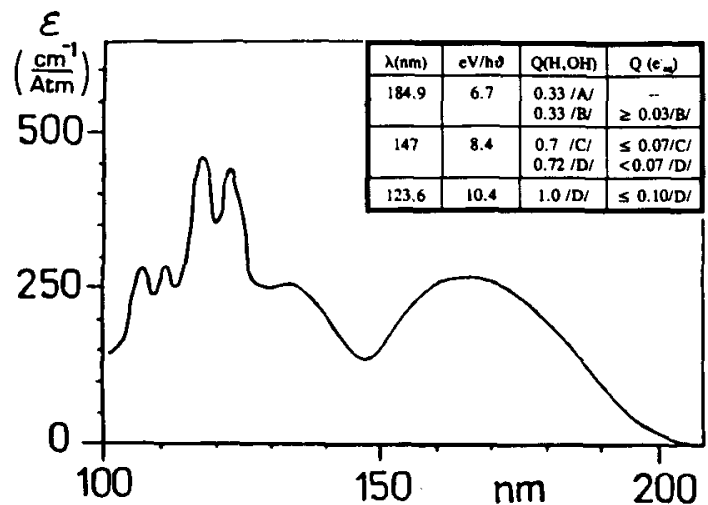

Figure 1. Absorption spectrum of water (Watanabe and Zelikoff 1953). Inset: Quantum energy $(\mathrm{eV} / \mathrm{hv})$ and quantum yields $(Q)$ of the primary products of water photolysis with VUV-light at 123.6, 147 and $184.9 \mathrm{~nm}$. (A) Dainton and Fowles 1965b; (B) Getoff 1968b; (C) Sokolov and Stein 1966; (D) Getoff and Schenck 1968.

pollutant in question. As sources for VUV-light, low pressure Hg-lamps emitting simultaneously $\lambda=184.9 \mathrm{~nm}(10 \%)$ and $253.7 \mathrm{~nm}(100 \%)$ are mostly used. For UV-light the same lamps were equipped with a Vycor-filter for absorption of the $184.9 \mathrm{~nm}$-line, as well as medium pressure $\mathrm{Hg}$-lamps, emitting several lines in the range of 250 to $578 \mathrm{~nm}$.

2.1a Water photolysis: Figure 1 shows the absorption spectrum of water as well as the quantum yield $(Q)$ of $\mathrm{H}, \mathrm{OH}$ and $e_{\mathrm{aq}}^{-}$of the primary products of water photolysis for three VUV-lines. The light at 123.6 and $147 \mathrm{~nm}$ can be produced by electrodeless special lamps (Getoff 1968a; Getoff and Schenck 1968). The VUV-light at these two wavelengths is at present of no practical interest, but is rather important with respect to the ozone chemistry in the upper atmosphere.

As can be seen from figure 1 , the VUV-line at $184.9 \mathrm{~nm}$ is absorbed by water and hence it can be photolytically decomposed:

$$
\begin{aligned}
& \mathrm{H}_{2} \mathrm{O} \rightarrow \mathrm{H}_{2} \mathrm{O}^{*} \rightarrow \mathrm{H}+\mathrm{OH}, \\
& 2 \mathrm{H}_{2} \mathrm{O}^{*} \rightarrow \mathrm{H}_{2} \mathrm{O}+\mathrm{H}_{2} \mathrm{O}^{* *} \text {, (super-excited molecules), } \\
& \mathrm{H}_{2} \mathrm{O}^{* *} \rightarrow \mathrm{H}_{2} \mathrm{O}^{+}+e_{\mathrm{aq}}^{-}, \\
& \mathrm{H}_{2} \mathrm{O}^{+}+\mathrm{H}_{2} \mathrm{O} \rightarrow \mathrm{OH}+\mathrm{H}_{\mathrm{aq}}^{+} .
\end{aligned}
$$

The free radicals so produced, $\mathrm{OH}, \mathrm{H}$ and $e_{\mathrm{aq}}^{-}$(solvated electrons), can initiate the decomposition reactions of water pollutants. In the presence of air, both $\mathrm{H}$ and $e_{\mathrm{aq}}^{-}$ are converted into peroxy-radicals.

$$
\begin{gathered}
\mathrm{H}+\mathrm{O}_{2} \rightarrow \mathrm{HO}_{2},\left(k_{5}=1.9 \times 10^{10} \mathrm{dm}^{3} \mathrm{~mol}^{-1} \mathrm{~s}^{-1}\right)^{1}, \\
e_{\mathrm{aq}}^{-}+\mathrm{O}_{2} \rightarrow \mathrm{O}_{2}^{-}, \quad\left(k_{6}=2 \times 10^{10} \mathrm{dm}^{3} \mathrm{~mol}^{-1} \mathrm{~s}^{-1}\right), \\
\dot{\mathrm{O}}_{2} \rightleftharpoons \mathrm{H}^{+}+\mathrm{O}_{2}^{--},(p K=4.8)(\text { Getoff and Prucha 1983, and } \\
\text { references therein). }
\end{gathered}
$$

\footnotetext{
${ }^{1}$ If not otherwise specified, the constants used $(k)$ are taken from Buxton et al (1988).
} 
The $\mathrm{HO}_{2}$ species are in general more reactive then the $\mathrm{O}_{2}^{--}$ones. The absorbed energy per quantum at $184.9 \mathrm{~nm}$ is: $E=6.7 \mathrm{eV} / \mathrm{hv}$, which was taken as basis for calculation of the "photochemical" $G$-values ${ }^{2}$ of: $G_{\mathrm{ph}}(\mathrm{H}, \mathrm{OH})=4.92$ and $G_{\mathrm{ph}}\left(e_{\mathrm{aq}}^{-}\right) \leqslant 0.45$ at $p \mathrm{H} 7$.

In the following the photoinduced decomposition of dichloromethane and tetrachloroethylene in aqueous solution as representatives of halogenated aliphatic pollutants are briefly discussed.

2.1b Dichloromethane: This compound is studied in the presence of air in neutral aqueous solutions as a model for the halogenated, simple aliphatic compounds (Getoff 1991, and references therein). Its major absorption lies in the VUV-range (see figure 2). Hence, using VUV-light of $184.9 \mathrm{~nm}$, both processes - direct electronic excitation of the substrate as well as photolysis of water - take place simultaneously. The yield of the photoinduced $\mathrm{Cl}$-cleavage is determined as a function of the absorbed light energy and is taken as an indicator of the decomposition process. This dependence is shown in figure 2. It is obvious that upto a VUV-dose of about $3.9 \times 10^{16} \mathrm{hv} \cdot \mathrm{ml}^{-1}$ the formation of $\mathrm{Cl}^{-}$ions is linear with absorbed energy and later on tends to a saturation value.

In addition to the photolysis of water (reactions (1) to (4)), a direct excitation of $\mathrm{CH}_{2} \mathrm{Cl}_{2}$ by the $184.9 \mathrm{~nm}$ VUV-light also takes place:

$$
\begin{aligned}
& \mathrm{CH}_{2} \mathrm{Cl}_{2} \longrightarrow * \mathrm{CH}_{2} \mathrm{Cl}_{2} \longrightarrow \longrightarrow \begin{array}{l}
\mathrm{CHCl}_{2}+\mathrm{H}, \\
\mathrm{CH}_{2} \mathrm{Cl}+\mathrm{Cl}^{\prime},
\end{array} \\
& \mathrm{Cl}^{-}+\mathrm{H}_{2} \mathrm{O} \rightarrow \mathrm{OH}+\mathrm{H}^{+}+\mathrm{Cl}^{-} .
\end{aligned}
$$

The $\mathrm{H}$-atoms are scavenged by $\mathrm{O}_{2}$, according to reaction (5), resulting in $\mathrm{HO}_{2}$ radicals which are converted into $\mathrm{O}_{2}^{-}$species (see reactions (5) to (7)). Both transients, $\dot{\mathrm{C}} \mathrm{HCl}_{2}$ and $\dot{\mathrm{C}} \mathrm{H}_{2} \mathrm{Cl}$ react with oxygen and the resulting peroxy-radicals subsequently lead

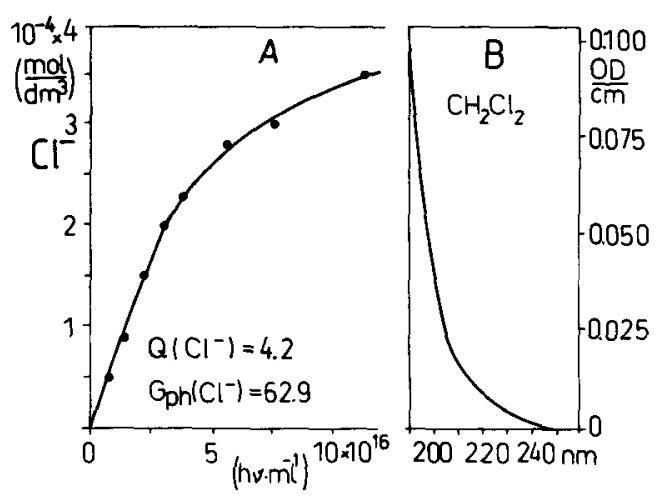

Figure 2. (A) Photoinduced Cl-cleavage from aqueous air-saturated $2 \times 10^{-4} \mathrm{~mol} \cdot \mathrm{dm}^{-3}$ $\mathrm{CH}_{2} \mathrm{Cl}_{2}$ using $\lambda_{\text {exc }}=184.9 \mathrm{~nm}$. (B) Absorption spectrum of $10^{-4} \mathrm{~mol} \cdot \mathrm{dm}^{-3} \mathrm{CH}_{2} \mathrm{Cl}_{2}$ in water $(p \mathrm{H} \sim 7)$.

\footnotetext{
${ }^{2} \mathrm{G}$-value $=$ number of formed or decomposed molecules per $100 \mathrm{eV}$ absorbed energy. For conversion to SI-units multiply the $G$-value by 0.10364 to obtain $G(x)$ in $\mu \mathrm{mol} \cdot \mathrm{J}^{-1} \cdot$. Initial $G$-value $\left(G_{i}\right)=$ yield before the degradation of final product occurs.
} 
to degradation of the pollutant (Getoff 1991):

$$
\begin{aligned}
& \dot{\mathrm{C}} \mathrm{HCl}_{2}+\mathrm{O}_{2} \rightarrow \dot{\mathrm{O}}_{2} \mathrm{CHCl}_{2} \rightarrow \mathrm{OH}+\mathrm{OCCl}_{2}, \\
& \dot{\mathrm{C}} \mathrm{H}_{2} \mathrm{Cl}+\mathrm{O}_{2} \rightarrow \dot{\mathrm{O}}_{2} \mathrm{CH}_{2} \mathrm{Cl} \rightarrow \mathrm{OH}+\mathrm{CO}+\mathrm{H}^{+}+\mathrm{Cl}^{-} .
\end{aligned}
$$

Phosgene $\left(\mathrm{OCCl}_{2}\right)$ is formed as an intermediate, but it is not stable in aqueous solution and hydrolyzes (Asmus et al 1985; Getoff 1989b):

$$
\mathrm{OCCl}_{2}+\mathrm{H}_{2} \mathrm{O} \rightarrow \mathrm{CO}_{2}+2 \mathrm{H}^{+}+2 \mathrm{Cl}^{-} \text {. }
$$

It has been shown (Packer et al 1980; Alfassi et al 1987) that by increasing the number of halogen atoms in the molecule also, the reactivity of the peroxy radical is enhanced. Therefore, it is expected that the $\dot{\mathrm{O}}_{2} \mathrm{CHCl}_{2}$ species are stronger in reacting with organic compounds than $\mathrm{O}_{2} \mathrm{CH}_{2} \mathrm{Cl}$ :

$$
\dot{\mathrm{O}}_{2} \mathrm{CHCl}_{2}+\mathrm{CH}_{2} \mathrm{Cl}_{2} \rightarrow \dot{\mathrm{C}} \mathrm{HCl}_{2}+\mathrm{CO}_{2}+2 \mathrm{H}^{+}+2 \mathrm{Cl}^{-} \text {. }
$$

The $\mathrm{OH}$ radicals from the water photolysis at $184.9 \mathrm{~nm}$ (reactions (1) and (4)) as well as those from reactions (9) to (11) can also react with $\mathrm{CH}_{2} \mathrm{Cl}_{2}$, whereas the $\mathrm{H}$ atoms resulting from reactions (1) as well as $e_{\text {aq. }}^{-}$from reaction (3) are converted into $\mathrm{O}_{2}^{-}$ species (reactions (5) to (7)). Hence,

$$
\begin{aligned}
\mathrm{CH}_{2} \mathrm{Cl}_{2}+\mathrm{OH} \longrightarrow \longrightarrow & \dot{\mathrm{C}} \mathrm{HCl}_{2}+\mathrm{H}_{2} \mathrm{O}, \\
\longrightarrow & \dot{\mathrm{C}} \mathrm{H}_{2} \mathrm{Cl}+\mathrm{ClOH}, \\
& k_{14}=0.9 \times 10^{8} \mathrm{dm}^{3} \mathrm{~mol}^{-1} \mathrm{~s}^{-1} .
\end{aligned}
$$

The two species, $\dot{\mathrm{C}} \mathrm{HCl}_{2}$ and $\dot{\mathrm{C}} \mathrm{H}_{2} \mathrm{Cl}$, are involved in the above reactions (10) and (11) followed by reactions (12) and (13). Finally, the peroxy radicals, $\mathrm{O}_{2}^{-}$and/or $\mathrm{HO}_{2}$ as well as $\mathrm{H}_{2} \mathrm{O}_{2}$ also contribute to the decomposition process of the substrate, e.g.:

$$
\begin{gathered}
\mathrm{O}_{2}^{-} / \mathrm{HO}_{2}+\mathrm{CH}_{2} \mathrm{Cl}_{2} \rightarrow \mathrm{HO}_{2}^{-} / \mathrm{H}_{2} \mathrm{O}_{2}+\mathrm{CHCl}_{2}, \\
\mathrm{H}_{2} \mathrm{O}_{2}+\mathrm{CH}_{2} \mathrm{Cl}_{2} \rightarrow \mathrm{OH}+\dot{\mathrm{C}} \mathrm{HCl}_{2}+\mathrm{H}_{2} \mathrm{O} .
\end{gathered}
$$

$\mathrm{OH}$ and $\dot{\mathrm{C}} \mathrm{HCl}_{2}$ radicals are consumed as discussed above. Based on the yield of $\mathrm{Cl}^{-}$ions the quantum yield, $(Q)$, as well as the "photochemical" $G$-value of the $\mathrm{Cl}^{-}$ ions were calculated and are given in figure 2 as an insert. The very high degradation yield obtained is due to the chain reactions initiated by the $\mathrm{OH}$ radicals which are generated in reactions (9) to (11) and then converted into $\dot{\mathrm{C}} \mathrm{HCl}_{2}$ and $\dot{\mathrm{C}} \mathrm{H}_{2} \mathrm{Cl}$ transients, (14a) and (14b). The propagation reactions are (10), (11), (13), (14a) as well as (14b).

2.1c Tetrachloroethylene: This pollutant has been chosen as representative of the halogenated ethylenes. Its absorption spectrum with $\lambda_{\max }=203 \mathrm{~nm}$ is shown in figure 3 , B. Obviously the $253.7 \mathrm{~nm}$ line makes a rather small contribution to the photoinduced decomposition process. Using $2 \times 10^{-4} \mathrm{~mol} \cdot \mathrm{dm}^{-3} \mathrm{Cl}_{2} \mathrm{C}=\mathrm{CCl}_{2}$ and a low pressure Hg-Lamp (184.9 and $253.7 \mathrm{~nm}$ ) it has been calculated that about $90 \%$ of the VUV-light is absorbed by the water. Hence, the primary products of the water photolysis initiate the degradation process. The rest of the absorbed energy is consumed by the substrate, leading to its decomposition (Getoff 1991). 


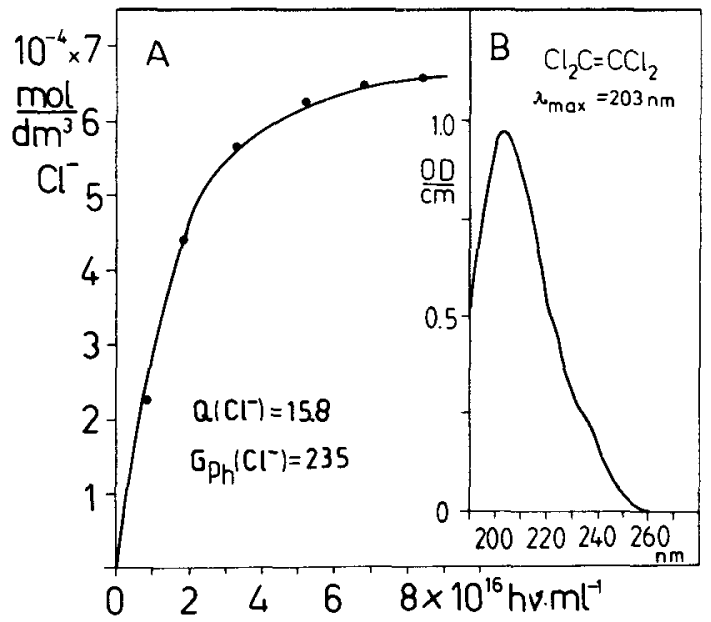

Figure 3. (A) Photoinduced Cl-cleavage of $2 \times 10^{-4} \mathrm{~mol} \mathrm{dm}^{-3}$ tetrachloroethylene in the presence of air at $30^{\circ} \mathrm{C}(\mathrm{pH} \sim 6 \cdot 4)$. (B) Absorption spectrum of $10^{-4} \mathrm{~mol} \cdot \mathrm{dm}^{-3} \mathrm{Cl}_{2} \mathrm{C}=\mathrm{CCl}_{2}$ in water $(p \mathrm{H} \sim 6.4) ; \epsilon_{203}=9870 \mathrm{dm}^{3} \mathrm{~mol}^{-1} \mathrm{~cm}^{-1}$.

The formation of the $\mathrm{Cl}$ ions from tetrachloroethylene as a function of the absorbed VUV-dose $(184.9 \mathrm{~nm})$ is presented in figure $3 \mathrm{~A}$. In this case also, chain reactions are operative, similar to the above described for the $\mathrm{CH}_{2} \mathrm{Cl}_{2}$-system, leading to a very high $Q$ - and $G_{\mathrm{ph}}$-yields (see figure 3). As decomposition products, in addition to $\mathrm{Cl}^{-}$ ions, small amounts of aldehydes, formic and oxalic acids were detected. However, these substances are also decomposed at higher VUV-doses.

It should be mentioned that the photoinduced degradation of various halogenated substances e.g. of trihalomethanes is investigated by various authors (e.g. Nicole et al 1991, and references therein).

\subsection{Photoinduced formation of $e_{\mathrm{aq}}^{-}$as promotor for pollutant degradation}

The solvated electrons $\left(e_{\mathrm{aq}}^{-}\right)$represent the basic form of the reducing primary species of water photolysis. In acid solution they can be transformed into $\mathrm{H}$-atoms and viceversa in alkaline media:

$$
\begin{gathered}
e_{\mathrm{aq}}^{-}+\mathrm{H}_{\mathrm{aq}} \rightarrow \mathrm{H}, \quad\left(k_{17}=2.3 \times 10^{10} \mathrm{dm}^{3} \mathrm{~mol}^{-1} \mathrm{~s}^{-1}\right), \\
\mathrm{H}+\mathrm{OH}_{\mathrm{aq}} \rightarrow e_{\mathrm{aq}}^{-},\left(k_{18}=2.5 \times 10^{7} \mathrm{dm}^{3} \mathrm{~mol}^{-1} \mathrm{~s}^{-1}\right) .
\end{gathered}
$$

Both, $\mathrm{H}$ and $e_{\mathrm{aq}}^{-}$are strong reducing transients and in the presence of air they are converted into peroxy radicals, (5) to (7). Each of their forms $\left(\mathrm{H}, e_{\mathrm{aq}}^{-}, \mathrm{HO}_{2}, \mathrm{O}_{2}^{-}\right)$can initiate the degradation of pollutants. The $e_{\mathrm{aq}}^{-}$can originate by photoexcitation of certain inorganic or organic substances in aqueous solution. Hence, for completeness their photoinduced formation is mentioned very briefly.

2.2a Formation of $e_{\mathrm{aq}}^{-}$from inorganic ions: Some photoexcited inorganic ions can lead to the formation of $e_{\mathrm{aq}}^{-}$. It has been found for the first time that $\mathrm{Fe}^{2+}$ can be oxidized by illumination to $\mathrm{Fe}^{3+}$ by ejection of $e_{\mathrm{aq}}^{-}$(Getoff et al 1960; Getoff 1962). The same observation has been made for halide ions (e.g. Jortner et al 1962) and for 
Table 1. Quantum yield $(Q)$ of photoinduced $e_{a q}^{-}$formation from some inorganic and organic compounds in aqueous solution.

\begin{tabular}{|c|c|c|c|c|}
\hline Substrate & $\lambda_{\mathrm{exc}}[\mathrm{nm}]$ & $\begin{array}{c}\text { Energy } \\
{[\mathrm{eV} / h v]}\end{array}$ & $Q\left(e_{2 q}^{-}\right)$ & References \\
\hline $\mathrm{OH}^{-}$ & 184.9 & 6.7 & $0.11)$ & \multirow{4}{*}{ Dainton and Fowles (1965a) } \\
\hline $\mathrm{Br}^{-}$ & 184.9 & 6.7 & 0.34 & \\
\hline $\mathrm{Cl}^{-}$ & 184.9 & 6.7 & 0.43 & \\
\hline $\mathrm{SO}_{4}^{2-}$ & 184.9 & 6.7 & $0-71)$ & \\
\hline $\mathrm{Fe}^{2+}$ & $253 \cdot 7$ & 4.9 & $0.07\}$ & \multirow[t]{2}{*}{ Airey and Dainton (1966) } \\
\hline $\mathrm{Fe}(\mathrm{CN})_{6}^{3-}$ & $253 \cdot 7$ & 4.9 & $0.66\}$ & \\
\hline $\mathrm{Fe}(\mathrm{CN})_{6}^{4-}$ & 214 to 228 & 5.79 to 5.4 & $\sim 0.9$ & Shirom and Stein (1971) \\
\hline $\mathrm{Fe}^{2+}$ & 292 to 314 & 4.2 to 3.9 & 0.0038 & Solar and Getoff (1979) \\
\hline $\mathrm{C}_{6} \mathrm{H}_{5} \mathrm{OH}$ & $253 \cdot 7$ & 4.9 & $0.03)$ & \multirow[t]{2}{*}{ Zechner et al (1976) } \\
\hline $\mathrm{C}_{6} \mathrm{H}_{5} \mathrm{OH}$ & 228.8 & 5.4 & $0.06\}$ & \\
\hline $\mathrm{C}_{6} \mathrm{H}_{5} \mathrm{O}^{-}$ & 253.8 & 4.9 & 0.17 & Grabner et al (1977) \\
\hline $\mathrm{C}_{6} \mathrm{H}_{5} \mathrm{O}^{-}$ & 228.8 & 5.4 & 0.27 & Getoff (1989a) \\
\hline $\mathrm{C}_{6} \mathrm{H}_{5} \mathrm{NH}_{2}$ & 276.7 & $4 \cdot 5$ & $0.06)$ & \multirow{3}{*}{ Köhler et al (1977) } \\
\hline $\mathrm{C}_{6} \mathrm{H}_{5} \mathrm{NH}_{2}$ & $253 \cdot 7$ & 4.9 & $0.27\}$ & \\
\hline $\mathrm{C}_{6} \mathrm{H}_{5} \mathrm{NH}_{2}$ & 228.8 & $5 \cdot 4$ & 0.28 & \\
\hline $\mathrm{C}_{6} \mathrm{H}_{5} \mathrm{NH}_{2}$ & 213.9 & 5.8 & 0.34 & Getoff (1989) \\
\hline $\mathrm{C}_{6} \mathrm{H}_{5} \mathrm{OPC}_{3}^{2-}$ & $253 \cdot 7$ & 4.9 & 0.028 & \multirow{2}{*}{$\begin{array}{l}\text { Getoff and Solar (1974) } \\
\text { Köhler and Getoff (1978) }\end{array}$} \\
\hline $\mathrm{C}_{6} \mathrm{H}_{5} \mathrm{OPO}_{3}^{\frac{3}{2}-}$ & 213.9 & 5.8 & $0-23$ & \\
\hline
\end{tabular}

other inorganic ions (Matheson et al 1963; Dainton and Fowles 1965b), e.g.:

$$
\begin{aligned}
& \mathrm{Fe}_{\mathrm{aq}}^{2+} \rightarrow \rightarrow\left(\mathrm{Fe}_{\mathrm{aq}}^{2+}\right)^{*} \rightarrow \mathrm{Fe}_{\mathrm{aq}}^{3+}+e_{\mathrm{aq}}^{-}, \\
& \mathrm{Cl}_{\mathrm{aq}}^{-} \rightarrow \rightarrow\left(\mathrm{Cl}_{\mathrm{aq}}^{-}\right)^{*} \rightarrow \mathrm{Cl}+e_{\mathrm{aq}}^{-}, \\
& \mathrm{C}_{\mathrm{aq}}^{-}+\mathrm{Cl} \rightarrow \mathrm{Cl}_{2}^{-}, \\
& \mathrm{SO}_{4 \mathrm{aq}}^{2-} \rightarrow \sim\left(\mathrm{SO}_{4 \mathrm{aq}}^{2-}\right)^{*} \rightarrow \mathrm{SO}_{4}^{-}+e_{\mathrm{aq}}^{-}, \\
& \mathrm{OH}^{-} \rightarrow\left(\mathrm{OH}^{-}\right)^{*} \rightarrow \mathrm{OH}+e_{\mathrm{aq}}^{-} .
\end{aligned}
$$

The quantum yields $(Q)$ of the photoinduced $e_{\mathrm{aq}}^{-}$resulting from some inorganic ions are given in table 1 .

2.2b Photoejection of $e_{\mathrm{aq}}^{-}$from organic compounds: It has been established that photoinduced electron ejection and formation of $e_{\mathrm{aq}}^{-}$from certain electronically excited organic substances in aqueous solution, having substitutents such as $-\mathrm{OH},-\mathrm{O}^{-}$, $-\mathrm{OCH}_{3},-\mathrm{OPO}_{3} \mathrm{H}_{2},-\mathrm{OPO}_{3} \mathrm{H}^{-},-\mathrm{COO}^{-},-\mathrm{NH}_{2},-\mathrm{NHCH}_{3},-\mathrm{N}\left(\mathrm{CH}_{3}\right)_{2}$ etc., can take place (Grossweiner et al 1963; Getoff 1989a, and references therein).

The ejection of electrons occurs from the singlet state $\left(S_{1}\right.$ or $\left.S_{2}\right)$, where the energy input is much lower than the ionization potential of a given compound in its gas phase. To explain this process, therefore, it is suggested that the dipole-dipole interaction between the polarized excited substrate molecules and the surrounding water molecules as well as the solvation energy of the resulting charged species contribute energetically and enable $e_{\mathrm{aq}}^{-}$formation (Getoff 1989a). 
The formation of $e_{\mathrm{aq}}^{-}$is also observed by illumination of dyes in aqueous solution, e.g. methylene blue (Vonach and Getoff 1983), a number of flavins (Getoff et al 1978), aromatic amines (Köhler et al 1977) etc.

The $Q\left(e_{\mathrm{aq}}^{-}\right)$-value strongly depends on several factors: excitation energy (see table 1), the structure of the substrate molecule as well as on the $p H$ and temperature of the solution (Getoff 1989a, and references therein). It has also been established that the formation of $e_{\mathrm{aq}}^{-}$takes place at the expense of the fluorescence (Köhler and Getoff 1974, 1976; Zechner et al 1976, 1981; Grabner et al 1977, 1980). This proves that the electron photoejection process occurs from the singlet state.

\subsection{Photoinduced decomposition of phenol}

Phenol is frequently observed as a pollutant in water. Its photoinduced degradation has been investigated in the presence of oxygen and small amounts of ozone (Getoff 1987). The reactivity of ozone with olefinic and aromatic compounds (without irradiation) can be designated as an electrophilic addition to the double-bond of the molecule (e.g. Bühler et al 1984, Sehested et al 1984, Hoigne 1985, Getoff 1989b, 1992, Gehringer et al 1992, and references therein).

As already mentioned above, the electronically excited aqueous phenol leads to the formation of $e_{\mathrm{aq}}^{-}$in addition to other processes (Grossweiner et al 1963; Jortner et al 1963; Grabner et al 1977, 1980; Getoff 1989b) e.g.:

$$
\begin{gathered}
\mathrm{C}_{6} \mathrm{H}_{5} \mathrm{OH} \leadsto * \mathrm{C}_{6} \mathrm{H}_{5} \mathrm{OH} \\
\longrightarrow \\
\longrightarrow e_{\mathrm{aq}}^{-}+\mathrm{H}_{\mathrm{aq}}^{+}+\mathrm{C}_{6} \mathrm{H}_{6} \dot{\mathrm{O}}, \\
\mathrm{H}+\mathrm{C}_{6} \mathrm{H}_{5} \mathrm{O} .
\end{gathered}
$$

The quantum yields $(Q)$ of the primary products $\left(e_{\mathrm{aq}}^{-}\right.$, resulting from $S_{1}$ - and $S_{2}$-states are given in table 1 . As already mentioned, in the presence of air $e_{\mathrm{aq}}^{-}$is converted

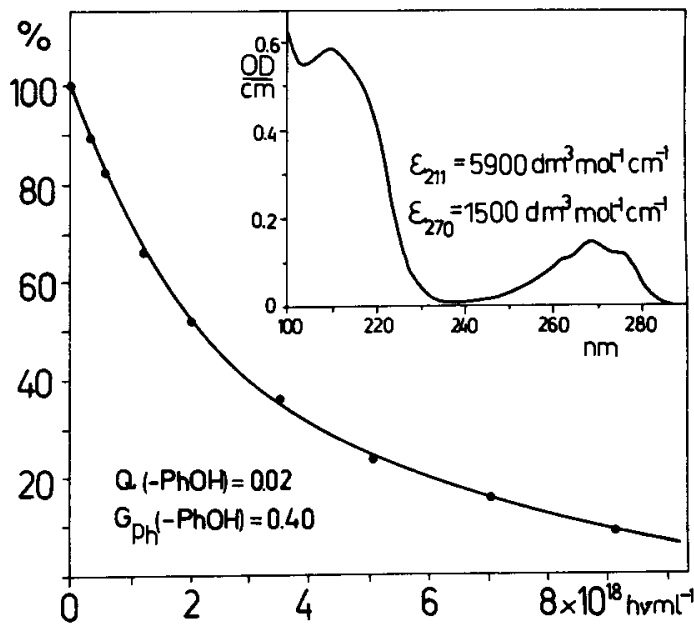

Figure 4. Photoinduced degradation (\%) of aqueous $10^{-4} \mathrm{~mol} \cdot \mathrm{dm}^{-3}$ phenol in the presence of $1.25 \times 10^{-3} \mathrm{~mol} \cdot \mathrm{dm}^{-3} \mathrm{O}_{2}$ and $1.1 \times 10^{-5} \mathrm{~mol} \cdot \mathrm{dm}^{-3} \mathrm{O}_{3}(p \mathrm{H}=7.5)$ as a function of the absorbed UV-dose $(\lambda=253 \cdot 7 \mathrm{~nm})$. Inset: absorption spectrum of $10^{-4} \mathrm{~mol} \cdot \mathrm{dm}^{-3}$ phenol. 
into peroxy radicals (see reactions (5) to (7)), which are subsequently involved in the decomoposition process.

The photoinduced degradation of phenol using UV-light $(253.7 \mathrm{~nm})$ in the presence of oxygen and small concentrations of ozone in neutral solutions is shown in figure 4. The achieved $Q$ - and $G_{\mathrm{ph}}$-values, as well as the absorption spectrum of phenol are given as inserts in figure 4.

The major reaction steps leading to the decomposition of phenol may start with the formation of phenoxyl radicals (reactions (24b) and (24c)), which exist in several resonance structures.<smiles>C=C=C1C(=O)C=CC=C1C=C</smiles>

Each of them can result in different final products or add on oxygen as shown below.

2<smiles>O=C1C=CC=CC1C1C(=O)C=CC=C1C1CCCCC1</smiles>

$\frac{+2 H}{\text { (enolizantion) }}$<smiles>Oc1ccccc1-c1ccccc1O</smiles>

(2.2' - biphenol)

Naturally, the above-mentioned peroxy radicals can also attack phenol and initiate its decomposition. In addition to this, each of the resonance structures can be scavenged by $\mathrm{O}_{2}$ as follows.

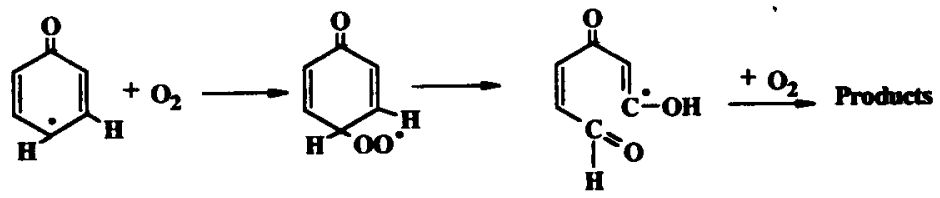

In the presence of sufficient oxygen in the solution, the pathway (27) will proceed preferentially, however, the exact reaction mechanism of the photoinduced phenol decomposition is not yet known. The yield and the kind of the products depend on the applied UV-dose, $p \mathrm{H}$ and the oxygen concentration. As final products of an incomplete degradation of the substrate, the following compounds were observed (Getoff 1987).
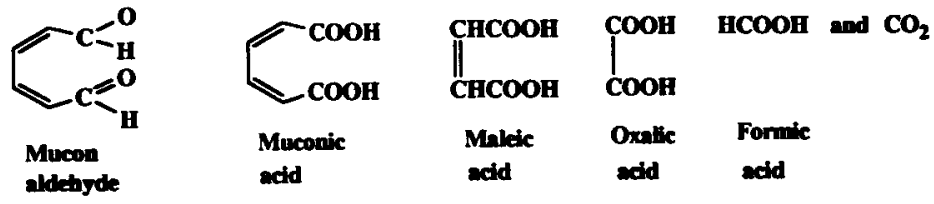

It might be mentioned that in addition to the $\mathrm{OH}, \mathrm{H}$ and $e_{\mathrm{aq}}^{-}$resulting in the VUV-water photolysis, the triplet state of the pollutant as well as the singlet oxygen $\left({ }^{1} \mathrm{O}_{2}\right)$ can be involved in the photochemical decomposition process in the presence of air. 


\section{Semiconductor-promoted pollutant degradation using solar energy}

\subsection{General remarks}

Since the discovery by Fujishima and Honda (1971) of water splitting to $\mathrm{H}_{2}$ and $\mathrm{O}_{2}$ using solar energy by means of an $n$ - $\mathrm{TiO}_{2}$-photoanode and metal cathode, separated by a membrane, a new pathway for research in photochemistry and photoelectrochemistry was found (Getoff et al 1977, Hantala et al 1979, etc.). The n-type semiconductors (e.g. $\mathrm{TiO}_{2}, \mathrm{SrTiO}_{3}, \mathrm{GaAs}$ etc.) have an excess of electrons $\left(e^{-}\right)$and, hence, are used as photoanodes or as suspensions (e.g. Izumi et al 1980, Vonach and Getoff 1981) or colloids (Hsiao et al 1983, Ahmed and Ollis 1984, Ollis 1985, 1990, Matthews 1985, 1988, Okamoto et al 1985, Al-Ekabi and Serpone 1988, Grabner et al 1991 etc.) for promoting the oxidation reaction. The p-type semiconductors (CdTe, GaP etc.) possess positive holes $\left(p^{+}\right)$in excess and serve as photocathodes in photoelectrochemical cells or for instance in the form of small particles and act as reduction photocatalysts (Bart 1979, Schiavello 1988, and references therein). Semiconductors can be also coated on glass (Dislich 1984) or on other carrier materials.

The application of semiconductors for photocatalyzed oxidation of aqueous pollutants is very recently discussed in an excellent review by Halmann (1992). Further, it might be mentioned that many papers dealing with $\mathrm{TiO}_{2}$ photocatalytic purification and treatment of polluted water are presented at the 1st International Conference in London, Canada (Al-Ekabi et al 1992).

On illuminating a $\mathrm{TiO}_{2}$ particle immersed in aqueous media with light of 315 to $450 \mathrm{~nm}$, band-bending takes place and electrons rise from the valence band $\left(E_{v}\right)$ to the conductivity band $\left(E_{c}\right)$ and, hence, a charge separation takes place (see figure 5 ). Based on this fact, each individual particle represents a redox-system and can promote reduction or oxidation processes depending on the experimental conditions. Each semiconductor has a characteristic band-gap (in eV; $1 \mathrm{eV}=23 \mathrm{kcal} / \mathrm{mol}$ ), e.g. for $\mathrm{TiO}_{2}$, $E_{G}=3 \mathrm{eV}$. Knowing the wavelength $(\lambda$ in $\mathrm{nm})$ of the light, one can calculate the energy per quantum: $(E$ in $\mathrm{eV} / h v)$ and vice versa.

$$
E=[1240 / \lambda(\mathrm{nm})](\mathrm{eV} / h v)
$$

The relative energy levels for some semiconductors are shown in figure 6. Silicon has the lowest energy-gap $\left(E_{G}=1 \cdot 1 \mathrm{eV}\right)$ but is not stable in aqueous solution.

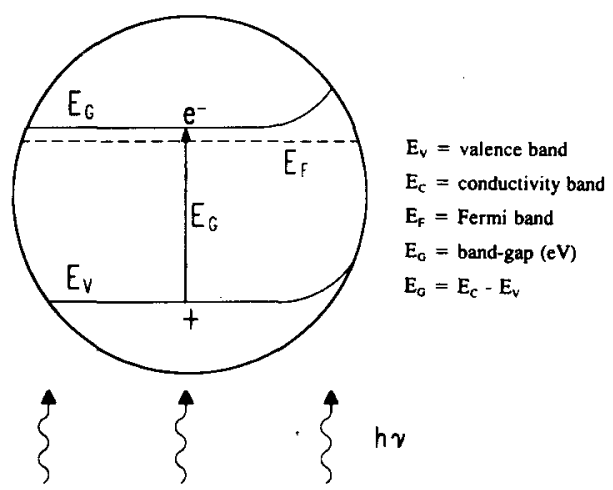

Figure 5. Simplified scheme of the energy levels of an illuminated $n$-type semiconductor particle. 


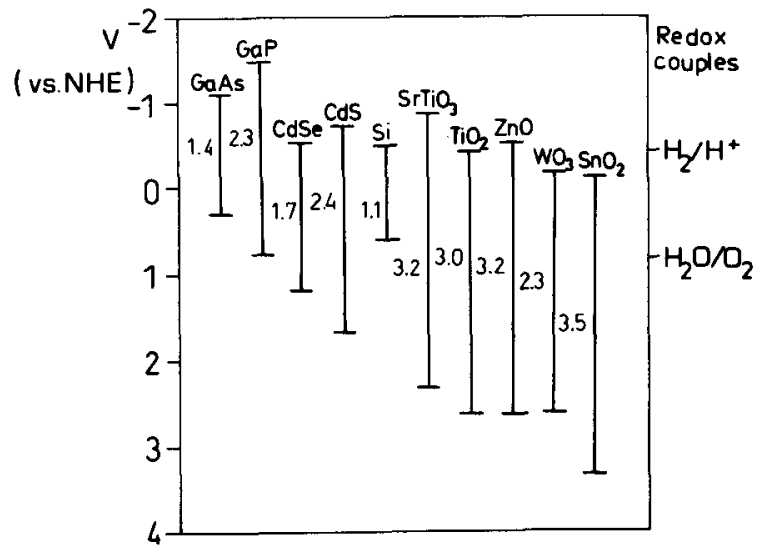

Figure 6. Relative energy levels ( $E_{G}$ in $\mathrm{eV}$ ) of some semiconductors (after Nozik 1980).

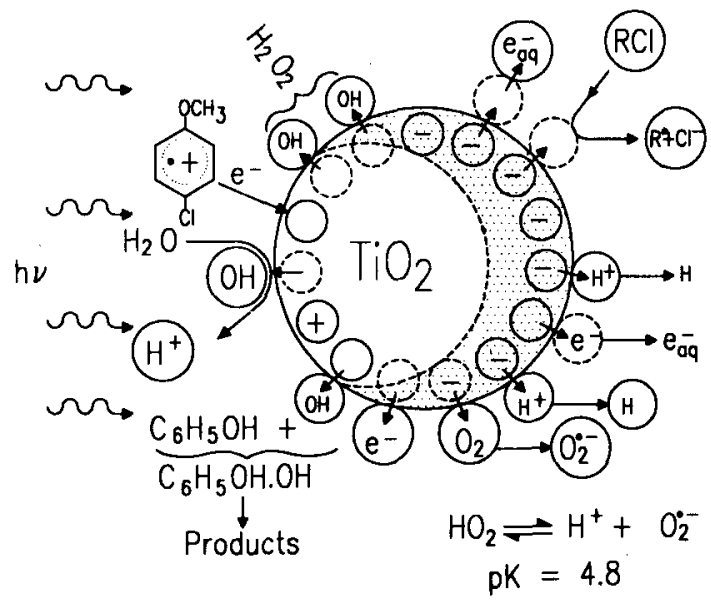

Figure 7. Some possible photoinduced processes on the surface of $\mathrm{TiO}_{2}$ particles in polluted water.

\subsection{Primary processes on semiconductor surfaces}

The photoinduced degradation of pollutants on the surface of e.g. $\mathrm{TiO}_{2}$ is not a simple process. In order to visualize the possible redox-reactions, a simplified scheme is presented in figure 7. The illuminated part of the $\mathrm{TiO}_{2}$-particle absorbs the lightenergy in $10^{-16} \mathrm{~s}$ and the electrons are moved from the $E_{v}$ to the $E_{c}$ (shadow side of the particle) bands. As a consequence of this charge separation, the illuminated part (positively charged holes, $h^{+}$) is able to decompose the adsorbed $\mathrm{H}_{2} \mathrm{O}$ molecules to OH radicals and $\mathrm{H}^{+}$ions. Also, an $e^{-}$can be transferred from a pollutant (having a suitable redox-potential) to $h^{+}$of the $\mathrm{TiO}_{2}$ particle (see figure 7). On the other hand, the $e^{-}$can be also transferred to adsorbed $\mathrm{H}^{+}, \mathrm{O}_{2}$ or the chlorinated pollutant initiating various reactions. It cannot be ruled out that some electrons can diffuse away from the $\mathrm{TiO}_{2}$ surface and become "solvated electrons" $\left(e_{\mathrm{aq}}^{-}\right)$as demonstrated by Walker (1967) on anode surfaces. 


\subsection{Photocatalytic degradation of pollutants}

For illustration of photocatalytic degradation, some major reactions taking place on the $\mathrm{TiO}_{2}$ surface in slightly acidic solution, are presented.

$$
\mathrm{TiO}_{2} \rightarrow \mathrm{TiO}_{2}^{+}+e^{-} \text {. }
$$

On the illuminated side of $\mathrm{TiO}_{2}$ particles (figure 7) a number of reactions can take place:

$$
\begin{aligned}
& \mathrm{TiO}_{2}^{+}+\mathrm{H}_{2} \mathrm{O} \rightarrow \mathrm{TiO}_{2}+\mathrm{OH}_{\mathrm{ads}}+\mathrm{H}^{+}, \\
& 2 \mathrm{OH} \rightarrow \mathrm{H}_{2} \mathrm{O}_{2}, \\
& \mathrm{OH}+\mathrm{H}_{2} \mathrm{O}_{2} \rightarrow \mathrm{H}_{2} \mathrm{O}+\mathrm{HO}_{2} .
\end{aligned}
$$

In the presence of a pollutant, e.g. 4-Cl-phenol, similar reactions can take place as studied by pulse radiolysis (Getoff and Solar 1988) as below.
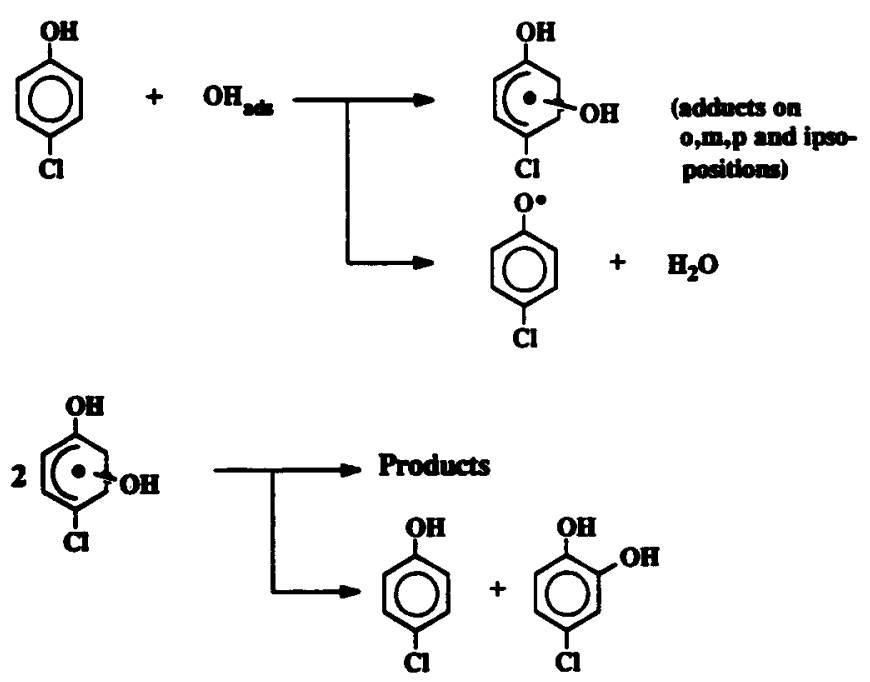

In competition with these processes, $\mathrm{O}_{2}$ can be scavenged as below resulting in peroxy-radicals.

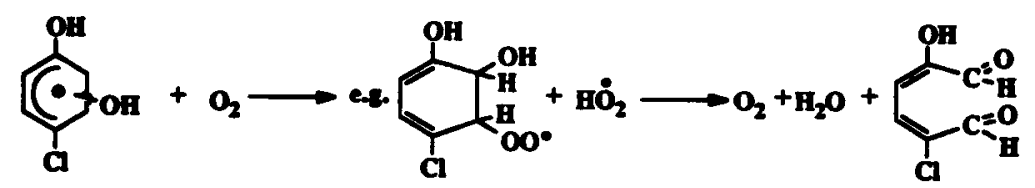

As a consequence of further $\mathrm{OH}$ attack and addition of oxygen, the resulting dialdehyde (35) can be decomposed to $\mathrm{CO}_{2}$ and $\mathrm{H}_{2} \mathrm{O}$ (see also reactions (25) to (27)).

Another pathway for $\mathrm{ClC}_{6} \mathrm{H}_{4} \mathrm{OH}$ degradation is the formation of a radical cation on the surface of $\mathrm{TiO}_{2}$ particles as indicated in figure 7 which can react further.

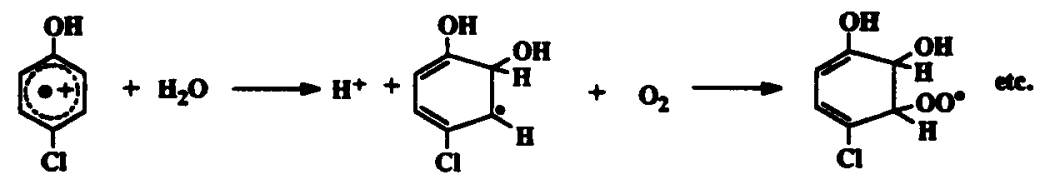


On the shadow side of the $\mathrm{TiO}_{2}$-particles (see figure 7) in slightly acid media some reactions can be initiated by the electrons in the presence of oxygen:

$$
\begin{gathered}
e^{-}+\mathrm{H}^{+} \rightarrow \mathrm{H}_{-\mathrm{ads}}, \\
\mathrm{H}_{\mathrm{ads}}+\mathrm{O}_{2} \rightarrow \mathrm{HO}_{2 \text { ads }},
\end{gathered}
$$

and from (7)

$$
\mathrm{HO}_{2} \rightleftharpoons \mathrm{H}^{+}+\mathrm{O}_{2}^{-}(p K=4 \cdot 8) \text {. }
$$

The $\mathrm{HO}_{2}$ and $\mathrm{O}_{2}^{--}$species can attack the water pollutants in the same way as the $\mathrm{OH}$ radicals followed by $\mathrm{O}_{2}$ addition (see reaction (35)).

As mentioned above, a number of papers have been published in recent years in the field of pollutant degradation assisted by semiconductors. Figure 8 shows some data concerning the oxidation rates of some pollutants in water (Mathews 1988). $\mathrm{TiO}_{2}$ (Degussa, P25 grade) was coated on the inside of a 7-m long 65-turn spiral of borosilicate glass ( $\varnothing 6 \mathrm{~mm}, 40 \mathrm{ml}$ solution was circulated through the spiral) illuminated with a 20 -W lamp.

It has been also found that the $\mathrm{TiO}_{2}$-assisted photodecomposition of 4-Cl-phenol is temperature-dependent (Hofstadler et al 1992). By studying the kinetics of the laser-induced phenol oxidation, it was observed that the $\mathrm{Cl}_{2}^{-}$species essentially contribute to the process (Grabner et al 1991; Li et al 1991). Further, it should be mentioned that $\mathrm{TiO}_{2}$ particles or colloids can also mediate the transformation of $\mathrm{CO}$ (Park et al 1988) as well as $\mathrm{CO}_{2}$ (Halmann 1978) into simple organic substances: In the absence of oxygen in the solution, the polymerisation of pollutants can also take place on the semiconductor surface.

With respect to photocatalytic water purification, there are still a number of problems to be solved. Although sunlight is free of cost and is readily available in many parts of the world, its intensity is rather low and it has to be collected and concentrated by appropriate means for the purpose of water purification on a technical scale.

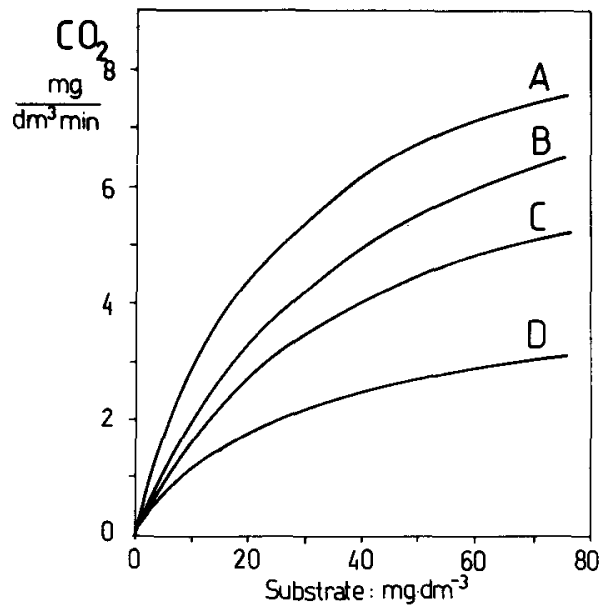

Figure 8. $\quad \mathrm{CO}_{2}$ rates observed by $\mathrm{TiO}_{2}$ oxidation of various substrates as a function of their initial concentrations: (A) 4-Cl-phenol, (B) phenol, (C) acetic acid, and (D) 2-propanol (after Matthews 1988). 
Further problems which have to be overcome are:

- to increase the low quantum yield of photocatalytic pollutant degradation.

- to improve the corrosion resistance and to reduce inhibition by poisoning of the semiconductor,

- the solvation of peculiar features of semiconductor coating on various support materials,

- lowering of the costs for semiconductor regeneration, water pumping etc.

Therefore, further investigations in this area are needed.

\section{Pollutant decomposition by ionizing radiation}

\subsection{General remarks}

In the last two decades, a relatively large number of papers have been published concerning radiolytic degradation of harmful substances in water. Hence, only some characteristic data for comparison with the above discussed photochemical methods will be presented. Gamma-rays as well as high-energy electrons can be used for production of reactive transients from water which can initiate the desired decomposition processes. Preference is given to high-energy electrons for several reasons: no manipulation with radioactive isotopes $\left(\right.$ e.g. ${ }^{60} \mathrm{Co}$ ) or their disposal required, easy regulation of the output power and simple handling in case of repair work as well etc. The modern electron accelerators (EA-machines) provide electrons with variable

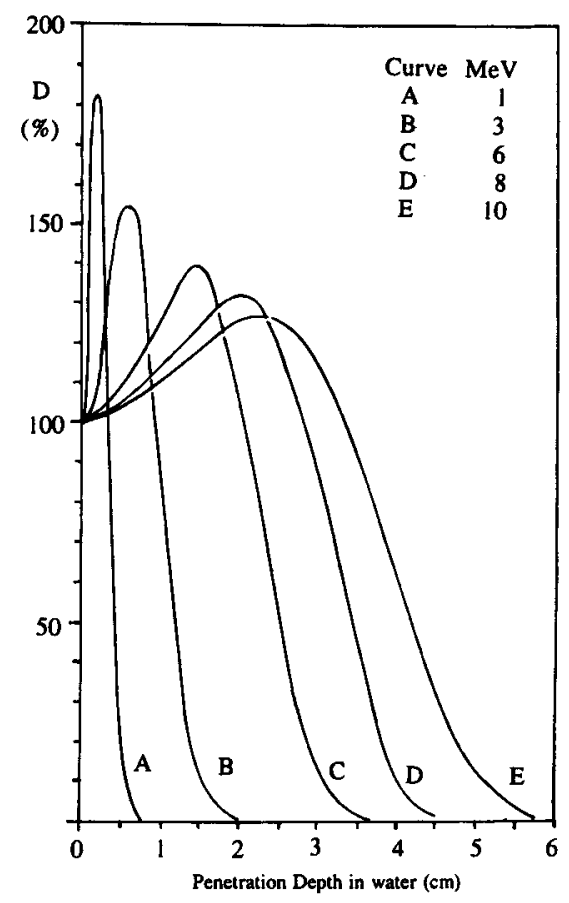

Figure 9. Depth-dose $(D \%)$ distribution in water at different electron energies. 
energy (e.g. from 0.5 to $2.8 \mathrm{MeV}$ ) and a rather high output power ( 80 to $100 \mathrm{~kW}$ ) with a conversion factor ( $\eta=$ electron power/electricity power) of about $80 \%$. EA-machines delivering electrons with energies of $4.5-5$ (output power $>400 \mathrm{~kW}$ ) or $10 \mathrm{MeV}$ $(25-50 \mathrm{~kW})$ can be also used for water purification. The electron penetration in water depends on their energy. Figure 9 shows the depth dose distribution ( $D$ in $\%$ ) in water for different electron energies (in $\mathrm{MeV}$ ). The depth dose of the applied electrons and the output power $(\mathrm{kW})$ of the EA-machine are determining factors for the quantity of purified water.

\subsection{Water radiolysis}

As a consequence of the interaction between the ionizing radiation and water, several transients and molecular products are formed. Their yields ( $G$-values) and major

Table 2. Radiolysis of water and some primary reactions.

Primary reactions:

$\mathrm{H}_{2} \mathrm{O} \underset{\rightarrow \mathrm{H}_{2} \mathrm{O}^{+}+e^{-}}{\stackrel{\mathrm{H}_{2} \mathrm{O}^{*} \rightarrow \mathrm{H}+\mathrm{OH}}{\mathrm{H}}}$

Gross reaction of water radiolysis (the $G$-values* at $p H 7$ are given in brackets):

$\mathrm{H}_{2} \mathrm{O} \rightarrow e_{\mathrm{aq}}^{-}, \mathrm{H}, \mathrm{OH}, \mathrm{H}_{2}, \mathrm{H}_{2} \mathrm{O}_{2}, \mathrm{H}^{+}, \mathrm{OH}_{a q}^{-}$ $(2 \cdot 7)(0.6)(2 \cdot 8)(0.45)(0.7)(3 \cdot 2)(0.5)$

Major primary reactions:

$$
\begin{aligned}
& \mathrm{H}+\mathrm{H} \rightarrow \mathrm{H}_{2} \\
& \left(k=1 \times 10^{10} \mathrm{dm}^{3} \mathrm{~mol}^{-1} \mathrm{~s}^{-1}\right) \\
& \mathrm{H}+\mathrm{OH} \rightarrow \mathrm{H}_{2} \mathrm{O} \\
& \left(k=2.5 \times 10^{10} \mathrm{dm}^{3} \mathrm{~mol}^{-1} \mathrm{~s}^{-1}\right) \\
& \mathrm{H}+e_{\mathrm{aq}}^{-} \rightarrow \mathrm{H}_{2}+\mathrm{OH}_{\mathrm{aq}}^{-} \\
& \left(k=2 \times 10^{10} \mathrm{dm}^{3} \mathrm{~mol}^{-1} \mathrm{~s}^{-1}\right) \\
& \mathrm{OH}+\mathrm{OH} \rightarrow \mathrm{H}_{2} \mathrm{O}_{2} \\
& \left(k=6 \times 10^{9} \mathrm{dm}^{3} \mathrm{~mol}^{-1} \mathrm{~s}^{-1}\right) \\
& \mathrm{OH}+e_{\mathrm{aq}}^{-} \rightarrow \mathrm{OH}_{\text {aq }}^{-} \\
& \left(k=2.5 \times 10^{10} \mathrm{dm}^{3} \mathrm{~mol}^{-1} \mathrm{~s}^{-1}\right) \\
& e_{\mathrm{aq}}^{-}+e_{\mathrm{aq}}^{-} \rightarrow \mathrm{H}_{2}+2 \mathrm{OH}_{\mathrm{aq}}^{-} \\
& \left(k=3 \times 10^{9} \mathrm{dm}^{3} \mathrm{~mol}^{-1} \mathrm{~s}^{-1}\right) \\
& e_{2 \mathrm{q}}^{-}+\mathrm{H}_{\mathrm{aq}}^{+} \rightarrow \mathrm{H} \\
& \left(k=2.3 \times 10^{10} \mathrm{dm}^{3} \mathrm{~mol}^{-1} \mathrm{~s}^{-1}\right) \\
& \mathrm{H}+\mathrm{OH}_{\mathrm{aq}}^{-} \rightarrow e_{\mathrm{aq}}^{-} \\
& \left(k=2.5 \times 10^{7} \mathrm{dm}^{3} \mathrm{~mol}^{-1} \mathrm{~s}^{-1}\right) \\
& \mathrm{OH} \rightleftharpoons \mathrm{H}_{m \mathrm{q}}^{+}+\mathrm{O}_{* \mathrm{q}}^{-} \\
& (p K=11.9) \\
& \mathrm{H}_{2} \mathrm{O}_{2} \rightleftharpoons \mathrm{H}_{2 \mathrm{q}}^{+}+\mathrm{HO}_{2 \mathrm{aq}}^{-} \\
& (p K=11 \cdot 65) \\
& \mathrm{N}_{2} \mathrm{O}+e_{\mathrm{aq}}^{-} \rightarrow \mathrm{OH}+\mathrm{OH}^{-}+\mathrm{N}_{2} \quad\left(k=0.9 \times 10^{10} \mathrm{dm}^{3} \mathrm{~mol}^{-1} \mathrm{~s}^{-1}\right) \\
& \mathrm{O}_{2}+e_{\mathrm{sq}}^{-} \rightarrow \mathrm{O}_{2}^{-} \\
& \left(k=2 \times 10^{10} \mathrm{dm}^{3} \mathrm{~mol}^{-1} \mathrm{~s}^{-1}\right) \\
& \mathrm{O}_{2}+\mathrm{H} \rightarrow \mathrm{HO}_{2} \\
& \left(k=1.9 \times 10^{10} \mathrm{dm}^{3} \mathrm{~mol}^{-1} \mathrm{~s}^{-1}\right) \\
& \mathrm{HO}_{2} \rightleftharpoons \mathrm{H}^{+}+\mathrm{O}_{2}^{-} \\
& (p K=4 \cdot 8) \\
& t-\mathrm{C}_{4} \mathrm{H}_{9} \mathrm{OH}+\mathrm{OH} \quad \mathrm{H}_{2} \mathrm{O}+t-\mathrm{C}_{4} \mathrm{H}_{8} \mathrm{OH} \\
& \left(k=5.5 \times 10^{8} \mathrm{dm}^{3} \mathrm{~mol}^{-1} \mathrm{~s}^{-1}\right)
\end{aligned}
$$

* $G$-value $=$ number of changed molecules per $100 \mathrm{eV}\left(1.60 \times 10^{-17} \mathrm{~J}\right)$ absorbed energy. For conversion in SI-units: multiply the $G$-value by 0.10364 to obtain $G(x)$ in $\boldsymbol{\mu} \mathrm{mol} \cdot \mathbf{J}^{-1}$.

$$
\begin{array}{rlrl}
\text { Absorbed dose units: } & & \\
1 \mathrm{rad}=100 \mathrm{erg} / \mathrm{g} \mathrm{H} & \mathrm{O} ; & 10^{6} \mathrm{rad}=1 \mathrm{Mrad}=10 \mathrm{kGy} \\
10^{2} \mathrm{rad}=1 \mathrm{Gray}(1 \mathrm{~Gy})=1 \mathrm{~J} / \mathrm{kg} \mathrm{H} \mathrm{O} ; & 10^{6} \mathrm{~Gy}=1 \mathrm{MGy}=1 \mathrm{kWs} / \mathrm{g} \mathrm{H}_{2} \mathrm{O} ; \\
10^{3} \mathrm{rad}=10 \mathrm{~Gy}=6.24 \times 10^{16} \mathrm{eV} / \mathrm{g} \mathrm{H}_{2} \mathrm{O} . &
\end{array}
$$


primary reactions are summarized in table 2. The common units for absorbed radiation dose are also given for convenience.

As shown above, in the presence of air $\left(0.25 \times 10^{-3} \mathrm{~mol} \cdot \mathrm{dm}^{-3} \mathrm{O}_{2}\right.$ at $\left.20^{\circ} \mathrm{C}\right)$ both $e_{\text {aq }}^{-}$and $\mathrm{H}$ atoms are converted into peroxy radicals which, together with the $\mathrm{OH}$ species, attack the available pollutants and initiate their degradation.

\subsection{Decomposition of chlorinated hydrocarbons}

Chlorinated hydrocarbons have been studied extensively by various research groups (e.g. Balkas et al 1970, 1971, Köster and Asmus 1971, Neumann-Spallart and Getoff 1979, Pikaev and Shubin 1984, Gehringer et al 1985, 1986, 1988, 1990, 1992, Getoff and Lutz 1985, Mönig et al 1985, Getoff 1986, 1989-1991, Proksch et al 1988, Draper et al 1989, etc.). Some data concerning radiation-induced degradation of several chlorinated aliphatic and olefinic hydrocarbons are presented in table 3 (Getoff 1989b). These pollutants frequency appear in drinking water. Obviously, their complete decomposition is achieved at a relatively low dose. In aerated water containing olefins or aromatic pollutants, the presence of ozone strongly enhances the degradation process (Masschelein 1982, Rice and Netzer 1984, Gehringer et al 1992, Getoff 1992 etc.).

The following major reaction can explain the ozone effect:

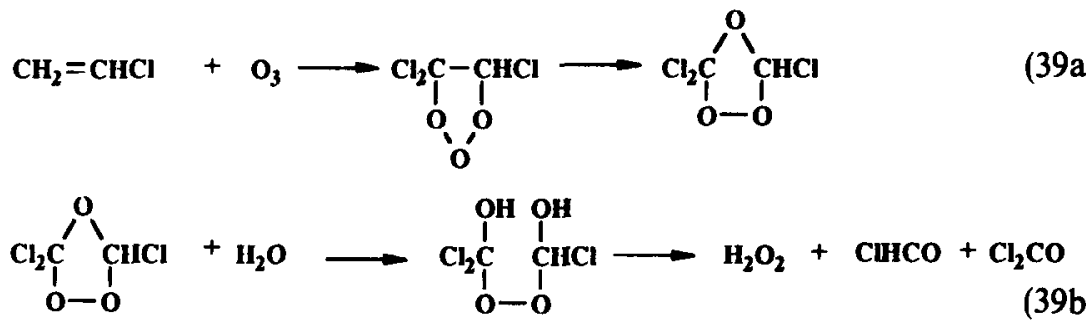

Table 3. Radiation induced decomposition of some chlorinated hydrocarbons in aerated water*. Applied dose: $1.9 \mathrm{kGy}$.

\begin{tabular}{|c|c|c|c|c|c|c|c|}
\hline \multirow[b]{2}{*}{$\begin{array}{l}\text { Sample } \\
\text { No. }\end{array}$} & \multicolumn{7}{|c|}{ Pollutants in water $/ \mu \cdot \mathrm{dm}^{-3}$} \\
\hline & $\begin{array}{l}\text { Treat- } \\
\text { ment }^{\dagger}\end{array}$ & $\mathrm{CH}_{2} \mathrm{Cl}_{2}$ & $\mathrm{CHCl}_{3}$ & $\mathrm{CCl}_{4}$ & $\mathrm{Cl}_{3} \mathrm{C}-\mathrm{CH}_{3}$ & $\mathrm{Cl}_{2} \mathrm{C}=\mathrm{CHCl}$ & $\mathrm{Cl}_{2} \mathrm{C}=\mathrm{CCl}_{2}$ \\
\hline \multirow[t]{2}{*}{1} & $\mathbf{U}$ & - & 32 & - & 0.7 & - & - \\
\hline & $\mathbf{I}$ & - & nd & - & nd & - & - \\
\hline \multirow[t]{2}{*}{2} & $\mathbf{U}$ & - & - & 25 & 0.2 & - & - \\
\hline & I & - & - & 1 & nd & - & - \\
\hline \multirow[t]{2}{*}{3} & $\mathrm{U}$ & 48 & - & - & 107 & $1 \cdot 1$ & - \\
\hline & I & nd & - & - & 0.8 & nd & - \\
\hline \multirow[t]{2}{*}{4} & $\mathrm{U}$ & 23 & $2 \cdot 3$ & $1 \cdot 1$ & 0.2 & - & - \\
\hline & I & nd & nd & 0.1 & nd & - & - \\
\hline \multirow[t]{2}{*}{5} & $\mathrm{U}$ & - & $2 \cdot 5$ & 0.2 & 4.5 & 361 & 0.2 \\
\hline & I & - & nd & nd & nd & nd & nd \\
\hline
\end{tabular}

${ }^{\dagger}$ U-unirradiated; I-irradiated; * the GC-analysis was performed by Dr U Bauer. Traceable limit: $<0 \cdot 1 \mu \mathrm{g} \cdot \mathrm{dm}^{-3}$

Abbreviations: nd =non-detectable; $\mathrm{Cl}_{3} \mathrm{C}-\mathrm{CH}_{3}=1,1,1$-trichloroethane; $\mathrm{CH}_{2} \mathrm{Cl}_{2}=$ dichloromethane; $\mathrm{Cl}_{2} \mathrm{C}=\mathrm{CHCl}=$ trichloroethylene; $\mathrm{CHCl}_{3}=$ chloroform; $\mathrm{Cl}_{2} \mathrm{C}=\mathrm{CCl}_{2}=$ tetrachloroethylene; $\mathrm{CCl}_{4}=$ carbontetrachloride. 


$$
\begin{aligned}
& \mathrm{ClHCO}+\mathrm{H}_{2} \mathrm{O} \rightarrow \mathrm{HCOOH}+\mathrm{Cl}^{-}+\mathrm{H}^{+} \\
& \mathrm{OCCl}_{2}+\mathrm{H}_{2} \mathrm{O} \rightarrow \mathrm{CO}_{2}+2 \mathrm{Cl}^{-}+2 \mathrm{H}^{+}
\end{aligned}
$$

These reactions can also occur without irradiation. They take place in the case of aromatic pollutants likewise.

\subsection{Decomposition of aromatic substances}

Steady state as well as pulse radiolysis studies of various aromatic pollutants in water have been published (e.g. Schuler et al 1976, Getoff and Solar 1986, 1988, Draper et al 1989, Getoff 1990b, 1992, Nickelsen et al 1992 etc.). For comparison with the above discussed photochemical methods, radiation-induced phenol decomposition is discussed in brief. As shown in figure 10 , at a dose of about $1.2 \mathrm{kGy}$ in the presence of oxygen the initial phenol is practically decomposed. However, due to competition reactions certain amounts of pyrocatechol, hydroquinone and hydroxyhydroquinone are formed. The initial $G$-values $\left(G_{i}\right)$ are given as an insert in figure 10 (Getoff 1986b). At higher doses these compounds and the resulting aldehydes and acids are decomposed to $\mathrm{CO}_{2}$ and $\mathrm{H}_{2} \mathrm{O}$. The major reactions taking place in this case are given below, (42) to (50) In addition to these, reactions (25) to (27) are also involved.
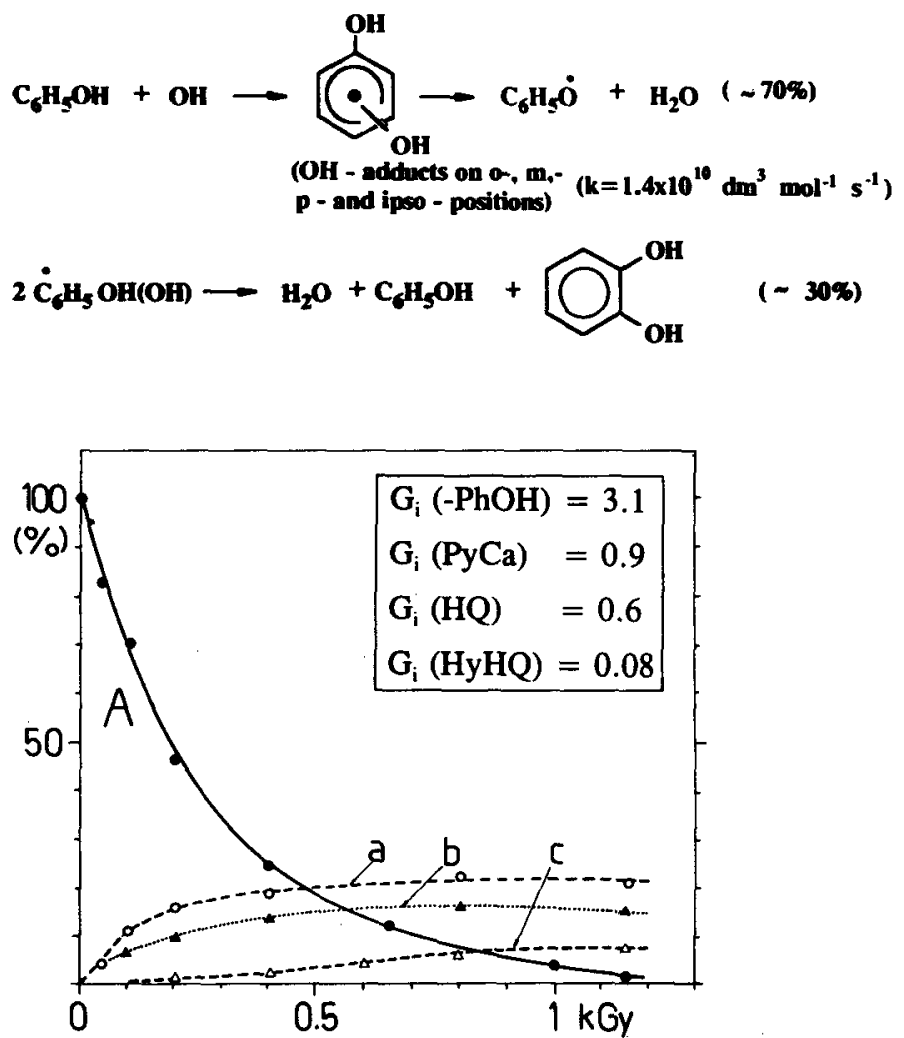

Figure 10. Decomposition of $10^{-4} \mathrm{~mol} \cdot \mathrm{dm}^{-3}$ phenol $(A)$ in the presence of $1.25 \times 10^{-3} \mathrm{~mol} \cdot$ $\mathrm{dm}^{-3} \mathrm{O}_{2}$, as well as formation of pyrocatechol (a), hydroquinone (b) and hydroxyhydroquinone (c) as a function of the absorbed dose at $\mathrm{pH} 7$; dose rate: $3 \mathrm{kGy} / \mathrm{h}$. Insert: Initial $G$-values $\left(G_{i}\right)$ of phenol decomposition and of the major products. 

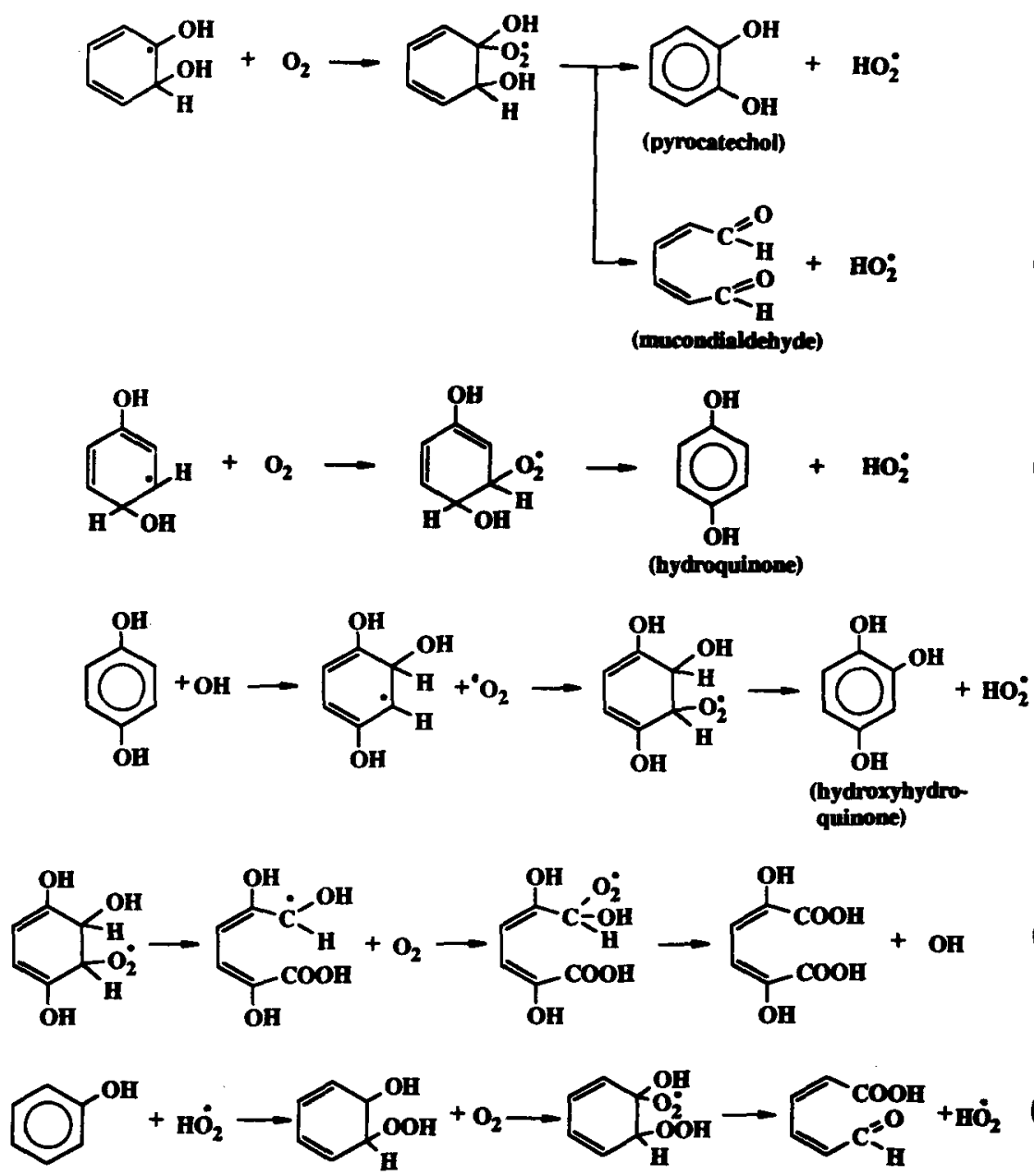

Based on the above data, it is now calculated that for a $50 \%$ decomposition of $10^{-4} \mathrm{~mol} . \mathrm{dm}^{-3}$ phenol by UV-light $(\lambda=254 \mathrm{~nm}, E=4.85 \mathrm{eV} / \mathrm{hv})$, an energy of $1.56 \mathrm{kGy}$ is needed. Using $\gamma$-rays or electrons in order to achieve the same decomposition degree, an energy of $0.2 \mathrm{kGy}$ is necessary. Obviously, the ionizing radiation is much more efficient than the UV-light in this case.

Finally, it should be mentioned that by means of pulse radiolysis of pollutant transients, their absorption spectra and the kinetics of their formation and decay, in addition to their chemical analysis, we can essentially elucidate their reaction mechanisms.

\section{Conclusion}

An attempt has been made to investigate the photochemical, photocatalytic and radiation-induced decomposition of pollutants in water. Special attention has been made to explain the primary processes initiating their degradation. On the other hand, a relationship is also established between the above-mentioned three pathways. 
Although a great deal of research work has been done concerning the degradation of water pollutants, further experiments are needed on a pilot scale in order to gain technical experience for construction of industrial plants for water purification.

\section{Acknowledgements}

The author would like to express his thanks to the Austrian Federal Ministry for Science and Research, the Fonds zur Förderung der wissenschaftlichen Forschung, and the Jubiläumsfonds of the Austrian National Bank for their financial support.

\section{References}

Ahmed S and Ollis D F 1984 Sol. Energy 32597

Airey P L and Dainton F S 1966 Proc. R. Soc. London A291 340

Al-Ekabi H, de Mayo P and Ollis D (eds) 1992 Abstr. Ist Intern. Conf. on $\mathrm{TiO}_{2}$ photocatalytic purification and treatment of water and air, London, Ontario

Al-Ekabi H and Serpone N 1988 J. Phys. Chem. 92 572b

Alfassi Z B, Mosseri S and Neta P 1987 J. Phys. Chem. 913383

Asmus K -D, Bahnemann D, Krichler K, Lal M and Mönig J 1985 Life Chem. 31

Balkas T, Fendler J H and Schuler R H 1970 J. Phys. Chem. 264497

Balkas T, Fendler J H and Schuler R H 1971 J. Phys. Chem. 26445

Bart A J 1979 Photochemistry 1059

Bühler R E, Staehelin J and Hoigne J 1984 J. Phys. Chem. 882560

Buxton G, Greenstock, Helman W P and Ross A B $1988 \mathrm{~J}$. Phys. Chem. Reference Data, 17 513-886

Dainton F S and Fowles P 1965a Proc. R. Chem. Soc. London A284 312

Dainton F S and Fowles P 1965b Proc. R. Chem. Soc. London A287 295

Dislich H 1984 Glass Sci. Technol. 2175

Draper R B, Fow M A, Pelizetti E and Serpone N 1989 J. Phys. Chem. 931938

Fujishima A and Honda K 1971 Bull. Chem. Soc. Jpn. 441148

Gehringer P, Proksch E, Eschweiler H and Sinovatz W 1990 Radiat. Phys. Chem. 35456

Gehringer P, Proksch E, Eschweiler H and Sinovatz W 1992 Appl. Radiat. Isot. 431107

Gehringer P, Proksch E and Sinovatz W 1985 Int. J. Appl. Radiat Isot. 4313

Gehringer P, Proksch E, Sinovatz W and Eschweiler H 1986 Z. Wasser Abwasser Forsch. 19196

Gehringer P, Proksch E, Sinovatz W and Eschweiler H 1988 Appl. Radiat. Isot. 391227

Getoff N 1962 Z. Naturforsch. 17b 87

Getoff N 1968a In Radiation Chemistry and its Applications (Vienna: IAEA) p. 172

Getoff N 1968b Monatsh. Chem. 99136

Getoff N 1986a Water Res. 201261

Getoff N 1986b Appl. Radiat. Isot. 371103

Getoff N 1987 AECL Accelerator Systems, Report, Deep River, Ontario

Getoff N 1989a Radiat. Phys. Chem. 34711

Getoff N 1989b Appl. Radiat. Isot. 40585

Getoff N 1990a (unpublished results)

Getoff N 1990b Radiat. Phys. Chem. 35432

Getoff N 1991 Radiat. Phys. Chem. 37673

Getoff N 1992 In Applications of isotopes and radiation in conservation of the environment (Vienna: IAEA) p. 153

Getoff N, Hartig K J, Kittel G, Peschek G A and Solar S 1977 Wasserstoff als Energieträger, Herstellung, Lagerung, Transport (in German) (Wien, New York: Springer)

Getoff N and Lutz W 1985 Radiat. Phys. Chem. 2521

Getoff N and Prucha M 1983 Z. Naturfosch. A38 589

Getoff N and Schenck G O 1968 Photochem. Photobiol. 8167

Getoff N, Scholes G and Weiss J J 1960 Tetrahedron Lett. 17

Getoff N and Solar S 1974 Monatsh. Chem. 105241 
Getoff N and Solar S 1986 Radiat. Phys. Chem. 28443

Getoff N and Solar S 1988 Radiat. Phys. Chem. 31121

Getoff N, Solar S and McCormick 1978 Science 201616

Grabner G, Köhler G, Zechner J and Getoff N 1977 Photochem. Photobiol. 26449

Grabner G, Köhler G, Zechner J and Getoff N 1980 J. Phys. Chem. 843000

Grabner G, Li G, Quint R M, Quint R and Getoff N 1991 J. Chem. Soc., Faraday Trans. 871097

Grossweiner L I, Swenson G W and Zwicker E F 1963 Science 141805

Halmann M 1978 Nature (London) 275115

Halmann M 1992 In Progress in photochemistry and photophysics (ed.) J F Rabek (Boca Raton, FL: CRC Press) vol. 5

Hantala R R, King R B and Kutal C (eds) 1979 Solar energy - chemical conversion and storage (Clifton, NJ: Humana)

Hofstadler K, Ruppert G, Bauer R, Heisler G and Novalic S 1992 (to be published)

Hoigne J 1985 In Radiation for a clean environment (Vienna: IAEA) p. 219

Hsiao G -Y, Lee C, Li and Ollis D F 1983 J. Catal. 82418

Hutzinger $\mathrm{O}$ et al (eds) 1982 Chlorinated dioxines and related compounds. Impact on the environment (Oxford: Pergamon)

Izumi I, Dunn W W, Wilbourn K O, Fan F, Ren F and Bard A J 1980 J. Phys. Chem. 843207

Jortner J, Ottolenghi M and Stein G 1962 J. Phys. Chem. 662037

Jortner J, Ottolenghi M and Stein G $1963 \mathrm{~J}$. Am. Chem. Soc. 852712

Köhler G and Getoff N 1974 Chem. Phys. Lett. 26525

Köhler G and Getoff N 1976 J. Chem. Soc., Faraday Trans. I 72101

Köhler G and Getoff N $1978 \mathrm{~J}$. Chem. Soc., Faraday Trans. I 741029

Köhler G, Rosicky C and Getoff N 1977 In Excited states in organic chemistry and biochemistry (eds) B Pullman and N Goldblum (Dordrecht: D Reidel) pp. 303-311

Köster K and Asmus K-D 1971 Z. Naturforsch. B26 1108

Li G, Grabner G, Quint R M, Quint R and Getoff N 1991 Proc. Indian Acad. Sci. (Chem. Sci.) 103505

Masschelein W J ed. 1982 Ozonization manual for water and wastewater treatment (Chichester. J Wiley \& Son)

Matheson M, Mulac W A and Rabani J 1963 J. Phys. Chem. 672613

Matthews R W 1985 Sun World 93

Matthews R W 1988 J. Catal. 111264

Mönig J, Göbl M and Asmus K-D 1985 J. Chem. Soc., Perkin Trans. 2647

Neumann-Spallart M and Getoff N 1979 Radiat. Phys. Chem. 13101

Nickelsen M G, Cooper W J, Kurucz C N and Walte I D 1992 Environ. Sci. Technol. 26144

Nicole I, DeLaat J, Dore M, Dugnet J P and Suty H 1991 Environ. Technol. 1221

Nozik A J 1980 Annu. Rev. Phys. Chem. A295 453

Okamoto K, Yamamoto Y, Tanaka H, Tanaka M and Itaya A 1985 Bull. Chem. Soc. (Japan) 582015

Ollis D F 1985 Environ. Sci. Technol. 19480

Ollis D F 1990 Solar-assisted photocatalysis for water purification. Proceeding 8th Int. Solar Energy Conversion Conference, Palermo, Italy

Packer J E, Willson R L, Bahnemann D and Asmus K -D 1980 J. Chem. Soc. Perkin Trans. II 296

Park H -R, Li G and Getoff N 1988 Z. Naturforsch. A43 1126

Pikaev A K and Shubin V N 1984 Radiat. Phys. Chem. 2477

Proksch E, Gehringer P, Sinovatz W and Eschweiler H 1988 Appl. Radiat. Isot. 391227

Rice R G and Netzer A.(eds) 1984 Handbook of ozone technology and application (Boston: Butterworth)

Rock J N 1974 Water Treatm. Exam. 23234

Schiavello M (ed) 1988 Photocatalysis and environment. Trends and applications (Dordrecht: Kluwer)

Schuler R H, Neta P, Zemet H and Fessenden R W $1976 \mathrm{~J} \mathrm{Am}$. Chem. Soc. 983825

Sehested K, Holcman J, Bejergbakke E and Hart E 1984 J. Phys. Chem. 884144

Shirom M and Stein G 1971 J. Chem. Phys. 553372

Sokolov U and Stein G 1966 J. Chem. Phys. 443329

Solar S and Getoff N 1979 Int. Hydrogen Energy 4403

Vonach T and Getoff N 1983 J. Photochem. 23233

Vonach W and Getoff N 1981 Z. Naturforsch. A36 876

Walker D C 1967 Can. J. Chem. 45807

Watanabe K and Zelikoff M 1953 J. Opt. Soc. Am. 43753

Zechner J, Köhler G, Getoff N, Tatischeff I and Klein R 1981 Photochem. Photobiol. 34163

Zechner J, Köhler G, Grabner G and Getoff N 1976 Chem. Phys. Lett 37297 